\title{
Instructional guidelines based on conceptions of students and scientists about economic and population growth within planetary boundaries
}

\author{
Irene Lampert ${ }^{1}$ (D) $\cdot$ Kai Niebert ${ }^{1} \cdot$ Markus Wilhelm $^{2}$
}

Received: 9 July 2020 / Accepted: 4 July 2021 / Published online: 25 August 2021

(C) The Author(s) 2021

\begin{abstract}
The burden placed by human activities on Earth is ever-increasing. Global environmental changes have profoundly affected the Earth's core systems and processes, thus, risking their stability. These core systems and processes are described in the planetary boundary framework. The drastic rate of environmental change over the last 200 years, which is also known as the Great Acceleration, has been depicted graphically by the International GeosphereBiosphere Program. This study is aimed to (1) examine the conceptions of students and scientists regarding socioeconomic growth within planetary boundaries, and (2) develop instructional guidelines based on the comparison of their conceptions. Accordingly, relevant conceptions of 22 junior and 20 senior secondary school students were analyzed. Scientists' conceptions were extracted by thoroughly analyzing nine publications, which were selected by systematic literature search. Student statements and scientific inferences were coded following established protocols. Our results indicated that junior and senior secondary school students considered global population growth to be the primary cause of global environmental changes. On the contrary, the scientists considered the quantity of natural resources consumed by rich countries in their economic pursuits as the most critical factor in environmental degradation. Based on our findings, we proposed instructional guidelines for planning lessons on changing current socioeconomic systems to enable humans to live within planetary boundaries.
\end{abstract}

Keywords Great acceleration - Model of educational reconstruction · Planetary boundary framework $\cdot$ Science education $\cdot$ Students' conceptions

Irene Lampert

irene.lampert@uzh.ch

Extended author information available on the last page of the article 


\section{Introduction}

The WHO (World Health Organization, 2020) suggests that global environmental changes (GEC), including climate change, stratospheric ozone depletion, loss of biodiversity, changes in hydrological systems, land degradation, and stresses on food-producing systems, have profound adverse impacts on human life. Earth's core systems depicted in the planetary boundary framework (Rockström et al., 2009; Steffen et al., 2015a) are equally affected. The planetary boundary framework describes nine planetary boundaries, including new substances and modified life forms, stratospheric ozone depletion, atmospheric aerosol loading, ocean acidification, freshwater use, climate change, biosphere integrity, biogeochemical flows (nitrogen, phosphorus), and land-system changes. This framework was developed to guide socioeconomic growth and development by determining the resilience capacity of the Earth system. These nine planetary boundaries are under intense anthropogenic pressure and have been transgressed (Rockström et al., 2009). Continual and permanent transgression of these planetary boundaries could result in excessively changing the Earth system, which, in turn, could limit the development of humanity (O'Neill et al., 2018; Rockström et al., 2009; Steffen et al., 2015a). The International Geosphere-Biosphere Program (IGBP) also has summarized important global social, economic, and Earth system trends graphically from 1750 to 2000. These are known as Great Acceleration graphs (Steffen et al., 2004). These graphs have been updated and differentiated based on socioeconomic trends of activities of countries from the Organization for Economic Cooperation and Development (OECD), emerging economies, and the rest of the world (Steffen et al., 2015b). The Great Acceleration graphs show that drastic global changes have been taking place to an extent and at a pace, which were unanticipated by scientists.

Scientific consensus suggests that global social and political changes must be instituted to ensure the stability of the Earth system (O'Neill et al., 2018; Rockström et al., 2009; Steffen et al., 2015a, 2015b). We need to raise public awareness to generate demand for implementing mitigation and policy measures that will help stabilize the Earth system to secure our collective future. Active public participation may expedite the process of raising awareness about GEC (Thackeray et al., 2020). Various means of representation and discourse could be used to reduce this gap (Komendantova \& Neumueller, 2020), including the planetary boundary framework and the Great Acceleration graphs, which are meant to raise awareness of science, politics, and the general public (Steffen et al., 2004).

GEC challenges humanity now and will continue to do so in the future. Hence, these challenges have to be addressed now to prevent future collapses. Against this backdrop, we hypothesized that educating junior (grade 7-9th ) and senior (grade 10-12th) secondary school students could be a crucial step towards addressing GEC as these students are future voting citizens and decision-makers. The planetary boundary framework summarizes GEC by describing planetary boundaries that affect the development of humanity, and by depicting the Great Acceleration graphs, which show the pace of GEC progression. We hypothesized that including the planetary boundary framework and the Great Acceleration graphs in planning lessons will help students to understand the complexity of GEC, raise awareness about the most jeopardized boundaries, and motivate them to start discussing possible solutions that will help to 
stay within the planetary boundaries. Students can also be taught to identify ecological systems that are endangered, facing destabilization, and may, in turn, endanger the stability of the Earth system as a whole.

Important aspects of GEC content must be understood clearly to find solutions for GEC. Planetary boundary framework aids students in this process helping them to understand the interconnectedness of the planetary boundaries, the importance of biodiversity for the stability of the Earth System, climate change, use of chemical substances, land-system change through intensive agriculture, and global transformation towards a more sustainable development. Therefore, we included the planetary boundaries and the Great Acceleration graphs in our interview studies in order to explore and compare the students' and scientists' conceptions and use their interpretations to develop instructional guidelines. This study was undertaken with two main objectives: firstly, to understand conceptions of Swiss junior and senior secondary school students and of scientists about economic and population growth within planetary boundaries; and secondly, to develop instructional guidelines based on the comparison of these conceptions to plan lessons on changing current socioeconomic systems for humans to live within these planetary boundaries. Hence, the following research questions (RQ) were framed to focus on our aims and carry out the study: RQ1: What conceptions do junior and senior secondary school students and scientists hold about economic growth, population growth, and planetary boundaries? RQ2: What are the similarities and differences between conceptions of junior and senior secondary school students and scientists? RQ3: What guidelines can be derived from the comparison of these conceptions for teaching purposes?

\section{Student conceptions about planetary boundaries, global environmental change, and socioeconomic growth}

Studies have been conducted to understand students' conceptions about GEC, economic development, and population growth. Studies have investigated if university students believe population growth to be the cause of GEC and if solutions arising from socioeconomic growth are sufficient to address the problem of environmental degradation. Mahler (2020) found that though the majority of the university students in Idaho (USA) believed population growth could be the main cause of GEC, they did not think that it was a local issue. Sternäng and Lundholm (2012) reported that most of the university students from different disciplines in Beijing believed that environmental problems were unavoidable if economic development needs to be achieved. We have previously reported on conceptions of students of grades 7-12 and have analyzed their ideas on the planetary boundary framework and nature of stability of the Earth system (Lampert \& Niebert, 2018; 2019). We observed that both scientists and students saw humanity as the main driver and accelerator of environmental changes and considered human actions as having grave repercussions for the environment, making it unstable and fraught with unintended changes to various Earth system processes. Shepardson et al. (2009) reported that a majority of $7^{\text {th }}$ grade students $(n=91)$ from three different schools in the Midwestern USA believed that humans would develop new technologies to counteract environmental changes. Similarly, Taiwanese undergraduate university students believed that science and technology were the determining factors for improving nature and prosperity (Liu \& Lin, 2014). A majority of Swedish business 
and economics university students proposed introducing taxes and environmental legislation as solutions to combat GEC (Ignell et al., 2017). In general, secondary school students often showed great interest in supporting pro-environmental actions (Chhokar et al., 2011; Lampert \& Niebert, 2019).

The relationships between our socioeconomic systems and the changing global environment define our future collective well-being. Hence, it is particularly important to understand the interpretation of students about these concepts (Sternäng \& Lundholm, 2012). Against this research backdrop, this study is based on two theoretical foundations:

1. The Theory of Embodied Cognition, which describes the role of experience and metaphors in learning.

2. The Conceptual Change Theory or Conceptual Reconstruction, which describes factors for successful learning of natural science content.

\section{Theories of embodied cognition and conceptual change}

Both theories are important for this study because they help to understand conceptions of students and scientists (theory of embodied cognition) and to develop instructional guidelines to help students reconstruct their pre-instructional conceptions to learn new scientific knowledge (conceptual change theory). The theory of embodied cognition emphasizes that we develop cognitive concepts based on our direct embodied experience, which have evolved from interaction with our environment, including pushing a door, filling up a cup, pressing a citron, crossing a finish line (Gropengiesser, 2007). In order to name those embodied concepts, Johnson (1987) introduced the term image schema such as the scale schema (adding water into a cub) or the containment schema (leaving or entering a room) (Johnson, 1987). However, not all concepts can be directly understood through direct embodied experience with our environment (Lakoff \& Johnson, 2008). We need our imagination to understand abstract concepts, including population growth, economic growth, or planetary boundary transgression. Since abstract concepts are not related to any direct experience, they are possible only if we are able to relate them to an already familiar embodied concept (Johnson, 1987; Lakoff \& Johnson, 2008). Therefore, when we describe imagined abstract concepts, we use the same terms that are used to describe direct understandable embodied concepts. Examples of describing abstract concepts include "...crossing thresholds..." (Rockström et al., 2009, p. 2) and "Population growth has pushed climate change..." (Ivan). As demonstrated by the citations, while describing abstract concepts, we often use metaphors (population pushes climate change) and image schemata (crossing a line) (Lakoff \& Johnson, 2008). In this study, we have used insights of the theory of embodied cognition to better understand the students' and scientists' conceptions about abstract phenomena, including population or economic growth and planetary boundary transgression.

Students bring their own preconceived conceptions into the classroom about abstract phenomena, such as global environmental change or socioeconomic growth, and their preconceived conceptions are not always compatible with the structure of the established scientific concepts that will be taught in the class (Duit \& Treagust, 2003; 
Treagust \& Duit, 2008). It is necessary that students re-construct their conceptions so as to enable them to learn the new content. This process of re-constructing based on conceptions is stated as conceptual change (Schneider et al., 2012). The conceptual change approach plays an important role in this study by highlighting the importance of pre-instructional abstract conceptions of students for learning new knowledge. Treagust and Duit (2008) argue that students ' pre-instructional conceptions should not be seen as obstacles for learning but as a starting point for the reconstruction of conceptions (Schneider et al., 2012). If a teacher is able to know about the pre-instructional conceptions of the students beforehand, then the teacher will have the opportunity to consider those conceptions during the planning of lessons and instructing. This practice supports the students during the process of reconstructing their conceptions into more scientific ones (Duit \& Treagust, 2003).

In this study, insights of the conceptual change theory have been used to develop instructional guidelines, which will help the students to reconstruct their conceptions. Instructional guidelines in this study were developed following the procedures of educational reconstruction, which determined the learning needs of students, revealed gaps between students' understandings and scientific conceptions, and helped to develop guidelines to address these gaps (Duit et al., 2012). The procedure of educational structuring is an integral part of the Model of Educational Reconstruction (MER) (Duit et al., 2012), which served as the research design for this study. MER was developed to improve science teaching and has been widely used in different fields, universities, and school levels for research and development in science education (Duit et al., 2012; Felzmann, 2017; Kattmann et al., 1997; Kersting, Henriksen, Bøe \& Angell, 2018; Reinfried et al., 2015). Hence, we used MER as this is the best research and development design tool for our study to formulate instructional guidelines, which would help to navigate the students' conceptions towards more scientific and consistent conceptions (Duit et al., 2012; Komorek \& Kattmann, 2008).

\section{Method}

The present study is based on the model of educational reconstruction (MER). We aimed to examine the students' and scientists' conceptions on socioeconomic growth within planetary boundaries, compare the conceptions of the two groups and develop instructional guidelines for teaching based on these findings. MER contains three assessment tasks that are linked to each other: (1) analysis of scientists' conceptions (key scientific concepts and models, and their perspectives), (2) analysis of students' perspectives regarding the selected topic (pre-instructional conceptions, ideas), and (3) comparison of the scientists' and students' perspectives on the chosen topic within the procedure of educational structuring in order to develop teaching guidelines (Duit et al., 2012). The analysis of the scientific subject content was aimed to critically clarify its structure from a pedagogical perspective. This was done by analyzing qualitative content and comparing relevant textbooks and publications (Duit et al., 2012; Gropengiesser, 2008; Mayring, 2015). Hence, the educational structuring and development of instructional guidelines emerged from the comparison of the students' and scientists' conceptions. These comparisons will reinforce fundamental decisions on emphasizing a particular topic while teaching (Duit et al., 2012). 


\section{Sampling procedure for scientists' conceptions}

Literature survey on planetary boundaries and Great Acceleration helped establish the critical scientific conceptions. Publications were selected by a search process equivalent to a systematic literature review and were analyzed. The selection process included five steps (Lavallée et al., 2014; Uman, 2011): (1) review question was established based on features of the planetary boundary framework and the Great Acceleration, (2) criteria for inclusion [only sources; those that explicitly focus on the planetary boundary framework itself; publications should be in English, published between 2009 and 2017 in scientific journals; leading publications by Rockström et al., 2009 and Steffen et al., 2015a; official documents of the Swiss Federation; peer-reviewed papers] and exclusion (publications that focused only on specific planetary boundaries such as climate change; letters to editors; blogs; websites; non-peer reviewed papers; predatory journals; books without references) were defined, (3) publications related to the review question within different databases and libraries (including nature.com, link.springer. com, Scopus, sciencemag.org, Google scholar, research portal of the University of Zurich) were searched, (4) publications based on inclusion and exclusion criteria were selected, and (5) publication quality in collaboration with the research working group were assessed. After applying the search criteria and discussing within the research group, nine publications were finally selected for this study: Bass, 2009; Dao et al., 2015; Frischknecht et al., 2016; Nash et al., 2017; Rockström et al., 2009; Rockström, and Klum, 2015; Schlesinger, 2009; Steffen et al., 2015a; Steffen et al., 2015 b.

\section{Research instrument}

Guided interviews are the most appropriate for investigating individual thought structures (Baur \& Blasius, 2019; Flick, 2015). Hence, we used this tool for our study (see the interview guide in the IJSME supplemental materials). The protocol enhanced discussion: open-ended questions, clarifying questions/interventions, and final questions/interventions combined with probing and follow-up questions. The structured protocol was developed based on the leading articles that discussed the planetary boundary framework and the Great Acceleration (Rockström et al., 2009; Steffen et al., 2015a; Steffen et al., 2015b). The protocol included the following: (1) Great Acceleration/growth, (2) boundaries/limits, (3) planetary boundary framework, (4) tipping points and planetary boundaries, (5) interaction of planetary boundaries, (6) hierarchy of planetary boundaries, (7) stability and instability of the Earth system, (8) human influence, (9) political action, and (10) reversibility and irreversibility of planetary boundary transgressions. The validity of the interview questions was explored using the CCSS (collect, check, sort, subsume) approach (Helfferich, 2011): (1) possible questions about the topics were collected; (2) the questions were checked for their suitability; (3) unsuitable questions were deleted and the remaining questions were sorted: open-ended questions, clarifying questions/interventions, final questions/interventions, etc.; (4) the remaining questions were subsumed within a logical order in the interview guide (Helfferich, 2011). Furthermore, a pilot test of the interview guide was conducted on a smaller group of secondary students to improve and ensure the understanding and relevance of the questions (Baur \& Blasius, 2019). 


\section{Sampling procedure for students' conceptions}

Relevant conceptions of 22 junior secondary school students (grades 7-9, mean age 14.85, standard deviation $0.75,12$ males, 10 females) and 20 senior secondary school students (grades 9-12, mean age 16.80, standard deviation 0.95, 13 males, 7 females) from different schools $(n=16)$ of central Switzerland were analyzed (mean interview length 30 minutes, standard deviation 8 minutes). All the participating students came from classes of standard secondary German-speaking schools in central Switzerland (Lucerne and Zurich areas). The majority of secondary school students in Switzerland are Swiss, while approximately $27 \%$ of students have an immigrant background (predominantly from Germany, France, Italy, Bosnia, or Serbia) (Federal Statistical Office, 2009).

Two in-depth interview studies were conducted to collect students' conceptions. Sampling of junior secondary (grades 7-9, 12 males, 10 females) students was performed through the snowball principle (Helfferich, 2011). Initially, students at a school in central Switzerland were asked for their willingness to participate in a study. This set of students, who first volunteered to participate in the study, subsequently brought in other interested students (snowball principle). People outside the circle of their acquaintances were also included to avoid sample homogeneity (Helfferich, 2011). During the second interview, multi-perspective information from senior secondary school students (grades 9-12, 13 males, 7 females ) was collected using an adapted sampling through the gatekeepers approach (Helfferich, 2011). Students working towards a secondary school teaching diploma at the University of Zurich were used as interviewers for the following reasons: (1) they were trained in conducting qualitative interviews for this study, and (2) it speeded up the process of obtaining a large sample. Each interviewer $(n=10)$ interviewed two secondary school students.

The first and second interview studies were conducted during October-November 2016 and October-November 2017, respectively. Validity within a qualitative survey situation could be met by the principle of openness because an identical replication of data in every new survey was not a priority (Baur \& Blasius, 2019). Greater validity to our survey was provided by following this principle of openness, and by keeping the survey situation natural, which had more subjective meaning, and thus, helped to unfold conceptions and perspectives. The reliability in the qualitative data collection was supported by careful designing of the interview situation and addressing it in the analysis. Written and/or verbal informed consent was obtained from each participant prior to the start of the study.

Quality control for content-analytical research methods was monitored (Mayring, 2015). During sample selection, structured procedures of sampling through snowball principle and gatekeepers were followed to maintain random sample validity (GlaserZikuda et al., 2020; Helfferich, 2011; Mayring, 2015). Documentation of overlapping conceptions was possible due to the relatively wide-ranging data corpus of 42 junior and senior secondary students (Glaser-Zikuda et al., 2020). The heterogeneity of the sample produced a wide range of data from students of different economic and social (urban, rural) backgrounds at various levels of schooling. However, the analysis of the students' conceptions was limited to students from the German-speaking part of Switzerland. 


\section{Analysis procedure}

Adapted methods of qualitative content and metaphor analyses were used to assess the conceptions of scientists and students, and a structured process of category building was used to establish comparisons (Gropengiesser, 2008; Mayring, 2000, 2015; Schmitt, 2005). The recorded interviews of the students were transcribed and analyzed following established procedures (Dresing et al., 2015). The student interview transcripts and the publications of the scientists were uploaded as separate files in MAXQDA (www.maxqda.com). Relevant statements of the students or citations of the publications associated with the research question were coded accordingly (Mayring, 2015). Statements with a similar content were assembled to build a category. During this coding process, both the categories of the scientific publications and the student interviews were compared regularly to uncover similarities and differences (Gropengiesser, 2008). The coded statements belonging to each category were summarized and the characteristics of the statements were discussed within the context of explication among the principal researchers (Gropengiesser, 2008). During this process, an adaptation of the metaphor analysis technique provided the methodological basis for the linguistic analysis of the statements and citations (Gropengiesser, 2008; Schmitt, 2005). Metaphors and metaphorical expressions associated with the research questions were collected and summarized. Individual conceptions for each category of student and scientist statements were formulated. The defined coding guide contained an openended collection of anchor examples as well as coding rules for the categories (Mayring, 2015).

To meet the quality criteria for content analysis (Mayring, 2015) and ensure semantic validity, the definitions, anchor samples, and coding rules were checked regularly for homogeneity during analysis. Validity was supported by comparing the analyzed results with published results from similar topic areas (ex. Forbes et al., 2015; Ignell et al., 2017; Nuraeni et al., 2017; Shepardson et al., 2009). Using the established coding guidelines, a second coding was carried out after about eight months to ensure stability. Intercoder reliability was addressed with the categories being checked against the coding guidelines in a second phase by a trained single second coder. Kappa coefficient (K), a measure of interrater reliability, yielded a value of 0.83 (values above 0.8 indicate high agreement, www.maxqda.com; Brennan \& Prediger, 1981). Divergent categories and codes were discussed between the principal researchers and the second coder to reach an interrater agreement. The plausibility of the results was supported by the fact that they were subjected to critical analysis in the research work group as well as during presentations at national and international conferences.

\section{Results}

We had formulated three research questions to support our hypothesis. Tables 1 and 2 give an overview of the conceptions of scientists and students about economic growth, population growth, and planetary boundaries (RQ1) as well as the incidence of each conception. The results about the incidence of each conception are based on in-depth interviews and qualitative content analysis; hence, we have not discussed about quantitative aspects in this paper. With a view to creating instructional guidelines for 
teaching, this study solely focused on qualitative thought patterns, which were revealed in the student interviews and scientific sources.

\section{Scientists' conceptions}

Table 1 summarizes the seven qualitatively different conceptions advocated by scientists, which were revealed by analyzing the scientific publications. These conceptions were verified by multiple reading, coding, and re-coding of the publications.

Steffen et al. (2015b) used metaphors to describe the role of humanity in becoming a "geological force" leading to the Great Acceleration (scientist conception 1). This force provoked GEC, which, in turn, put pressure on the most important Earth systems, thereby, resulting in their destabilization (Rockström et al., 2009; Rockström \& Klum, 2015; Steffen et al., 2015b). Steffen et al. (2015b) demonstrated that an increase in $\mathrm{CO}_{2}$ emissions correlated with an increase in energy consumption and real gross domestic product in dollars per capita (GDP) (scientist conception 2). Scientists considered that (unsustainable) economic growth led to GEC (scientist conception 3). One way of demonstrating this connection between economic activity and GEC is by comparing the increase of GDP in dollars per capita, which is the main indicator of economic growth, with the increase in $\mathrm{CO}_{2}$ emissions. The use of global Earth system resources by a country is connected with its real GDP in dollars per capita: the higher the GDP, the greater is the resource consumption. Analysis of the scientific publications reveals metaphorical conceptions of the phenomenon "Economy as an Organism" (Wang et al., 2013). Similar to any other living organism, the economy needs food (resources) to sustain itself and grow (economic growth) (citation conception 7; Rockström \& Klum, 2015). Literature suggests that developed countries have the lowest population growth but the highest GDP in dollars per capita rates, which means that GEC in the Earth system, which are represented by the Great Acceleration graphs and planetary boundary framework, is almost entirely driven by economic activities of the developed countries (Lampert \& Niebert, 2019). Therefore, the growth of the world's population cannot be seen as the main driver of GEC. Even though developing countries have the highest population growth, they have the lowest GDP growth and the lowest $\mathrm{CO}_{2}$ emissions (Malm \& Hornborg, 2014) because a large section does not even participate in the fossil economy. Almost $1 / 3^{\text {rd }}$ of the world's population has no access to electricity (Malm \& Hornborg, 2014; Steffen et al., 2015b). Although scientists do not completely discount the impact of population size on the Earth system, they do clearly point out that the collective economic activities of a country have a much greater environmental impact than its mere number of people. Scientists explain that the exponential growth of the world's population will soon slow to a complete halt (scientist conception 4). On the basis of the latest data available, it is projected that the world's population will stabilize at approximately 10 to 11 billion by the end of the $21^{\text {st }}$ century (Steffen et al., 2015b). Some countries already are with negative population growth such as Japan, Germany, and Eastern European countries. If this is the case, it would mean that economic growth, rather than population growth, would be the main problem that needs to be addressed in the 
Table 1 Scientists' conceptions

Scientists' conceptions

1 Socioeconomic Growth Leading to the Great Acceleration

2 Economic Growth Driving $\mathrm{CO}_{2}$ Emissions

3 Economic Growth Leading to Global Environmental Change

4 Decline in Exponential Population Growth

5 Planetary Boundary Compliance through Green Economic Growth
"In summary, the Great Acceleration marks the phenomenal growth of the global socio-economic system, the human part of the Earth System. It is difficult to overestimate the scale and speed of change. In little over two generations - or a single lifetimehumanity (or until very recently a small fraction of it) has become a planetary-scale geological force." (Steffen et al., 2015b, p. 93f)

"The rise in carbon dioxide concentration parallels closely the rise in primary energy use and in GDP, showing no sign yet of any significant decoupling of emissions from either energy use or economic growth." (Steffen et al., 2015b, p. 89)

"Current global environmental change is the consequence of interconnected causes occurring at a global scale ... [such as] technological and economic development (real GDP tripled since 1980)." (Dao et al., 2015, p. 6)

"Population continued to grow strongly through the 2001-2010 period with little sign of slowing. However, changes in fertility rates foreshadow that exponential population growth will soon be over. Global average fertility rate has dropped to 2.5 children per woman. Humanity has passed 'peak child' and population is expected to reach between 10 and 11 billion people later this century." (Steffen et al., 2015b, p. 89)

"This study ... has the aim to develop recommendations for a set of environmental limits [planetary boundaries] for a Green Economy, by translating the limits of our planet to the context of Swiss demand. If all these limits are respected by the proposed deadline, and assuming that countries around the world make comparable efforts, then the overall environmental impact could be considered managed." (Dao et al., 2015, p. 4)

"We have the tools to do what's required - the intelligence, creativity, and technological know-how. We can reverse the negative trends. We can feed nine billion people without destroying our forests. We can deliver power to our economies without burning fossil fuels. But the only way to
$86 \%$

1

\section{$8 \%$}


Table 1 (continued)

\begin{tabular}{|c|c|c|c|}
\hline & Scientists' conceptions & Example quotation & $\begin{array}{l}\text { Publication } \\
\text { incidence }\end{array}$ \\
\hline & & $\begin{array}{l}\text { achieve prosperity is through green } \\
\text { growth." (Rockström \& Klum, 2015, p. 24) }\end{array}$ & \\
\hline 6 & $\begin{array}{l}\text { Planetary Boundary Compliance through } \\
\text { Decoupling of Economic Growth and } \\
\text { Environmental Impact }\end{array}$ & $\begin{array}{l}\text { "He [Arnold Tukker] started with some } \\
\text { thoughts on } 2050 \text { footprint limits on } \\
\text { greenhouse gas emissions, water, land and } \\
\text { materials and listed environmental policies } \\
\text { from Europe and Asia aiming at a } \\
\text { decoupling of economic growth and } \\
\text { environmental impacts. Such a decoupling } \\
\text { requires monitoring for which Exiobase, } \\
\text { multi-regional input output tables, are be- } \\
\text { ing developed." (Frischknecht et al., 2016, } \\
\text { p. 603) }\end{array}$ & $57 \%$ \\
\hline & & $\begin{array}{l}\text { "Despite this critical situation Switzerland has } \\
\text { already done quite some successful efforts } \\
\text { as shown by the relative decoupling } \\
\text { between the evolution of the Swiss } \\
\text { consumption (GDP in constant CHF) and } \\
\text { the evolution of the footprints. For } \\
\text { respecting the limits in the future, domestic } \\
\text { efforts should be intensified and reduction } \\
\text { efforts on impacts of Swiss imports should } \\
\text { be started." (Dao et al., 2015, p. 70) }\end{array}$ & \\
\hline 7 & $\begin{array}{l}\text { Economic Growth Is Still Coupled with } \\
\text { Environmental Impact }\end{array}$ & $\begin{array}{l}\text { "On the other hand, greenhouse gases are still } \\
\text { rising rapidly, threatening the stability of } \\
\text { the climate system, and tropical forest and } \\
\text { woodland loss remains high. The pursuit of } \\
\text { growth in the global economy continues, } \\
\text { but responsibility for its impacts on the } \\
\text { Earth system has not been taken." (Steffen } \\
\text { et al., 2015b, p. 94) }\end{array}$ & $57 \%$ \\
\hline
\end{tabular}

future. Rockström and Klum (2015) describe that perpetual growth within planetary boundaries is both possible and desirable:

"The debate about whether it's possible to have infinite growth in the face of rising environmental problems and resource constraints, continues to be a heated one. ... Based on the evidence before us, we're convinced that humanity's future lies in growth within a safe operating space on Earth. For 40 years, like Moses in the unforgiving wilderness of the Sinai desert, environmentalists have wandered around advocating 'limits to growth' with very little or no success. Now it's time to leave the wilderness and engage with the world in a much more constructive paradigm of 'growth within limits'." (Rockström \& Klum, 2015, p. 131)

Planetary boundaries do not limit growth and development but rather push it towards a certain direction. The scientists have suggested two strategies to achieve perpetual growth within these boundaries: 
1. An economic system that exists in balance with the Earth system is termed as a green economy or green growth (scientist conception 5), and this should be the focus of global policy (Steffen et al., 2015b). Scientists observe that changes in our environment, including climate system, ozone layer, or global hydrological cycle, have a direct impact on global economic and social structures: environmental risks become socioeconomic risks. Consequently, for future global welfare, we must prevent irreversible changes to our environment that destabilize global markets.

2. Maintaining green economic growth within these boundaries by decoupling growth from environmental damage must take place. For instance, developed countries, such as Switzerland, currently aim to decouple economic growth from environmental impacts (scientist conception 6). The goal is to try to improve resource productivity and efficiency at a rate that enables the economy to grow faster than it consumes resources.

However, Steffen et al. (2015b) have rightly pointed out that there has been little decoupling of economic growth from environmental impacts and resource use to date (scientist conception 7). Furthermore, it is known that more efficient use of a certain resource does not lead to a reduction in resource consumption; rather, paradoxically, it results in higher consumption through increased resource use, also known as the rebound effect. Resource productivity and efficiency cannot ensure planetary boundary compliance in an isolated way. More efficient technologies lower costs that free money for additional consumption (O’Neill et al., 2018).

To summarize, the planetary boundaries aim to guide socioeconomic growth and development by defining a safe level for the use of non-renewable fossil resources and to increase the protection of biodiversity in order to keep environmental conditions similar to the Holocene (Rockström et al., 2009). The scientists show that the higher the GDP growth of a country, the greater is the resource consumption and, therefore, the higher is the influence on GEC. Developed countries have the lowest population growth but the highest GDP growth. Developing countries have the lowest GDP growth but the highest population growth (Friedlingstein et al., 2014; Malm \& Hornborg, 2014; Steffen et al., 2015b). Therefore, developed countries with a high economic growth have the biggest impact on GEC. Changes in our environment have a direct impact on the global economic and social structures. Hence, the economy has an interest to comply with the planetary boundaries. Scientists promote green economic growth aiming at decoupling growth from environmental damage in order to stay within the planetary boundaries (Friedlingstein et al., 2014; Rockström et al., 2009; Steffen et al., 2015b). However, to date, there has been no permanent decoupling of economic growth from environmental impacts (Steffen et al., 2015b).

\section{Students' conceptions}

Initially, German interview transcripts were analyzed, and the relevant statements were then translated to illustrate the students' conceptions. All translated statements were checked by an English native speaker, who was fluent in both English and German. Analysis of the German transcripts revealed eight different conceptions of the students, which are summarized in Table 2. 
About half of the junior and senior secondary students believed that world population growth was the main cause of the Great Acceleration. Both the groups argued that the increase in population growth had led to more $\mathrm{CO}_{2}$ emission, increased loss of biodiversity, and greater environmental damage (student conception 1). The senior secondary students were able to discuss more complex rationales (use of non-renewable fossil resources, land system use, etc.) regarding the relationship of population growth to GEC compared with the junior secondary students. The students' statements that more leads to even more ("with more people, more cars are driven") reveal the scale schema, which is considered to be one of the most pervasive image schemata in the world (Johnson, 1987).

Almost all of the students cited $\mathrm{CO}_{2}$ emissions as an example to describe the role of population size in changing the Earth system (student conception 2). They also considered continued population growth to be responsible for biodiversity loss and climate change. However, the senior secondary students were able to provide more adequate descriptions for the causes of biodiversity loss. For example, they described that instead of hunting, it is the food production with monocultures, which is a cause of biodiversity loss. $\mathrm{CO}_{2}$ emission is considered to be a problem leading to global warming, which, in turn, is considered to be a cause of the Earth's instability (student conception 3, Ivan). Approximately, half of the students also believed that global environmental degradation would continue to increase as the world's population will continue to grow exponentially (student conception 4).

Junior and senior secondary students debated for the term exponential population growth. However, exponential growth is a difficult concept to fully understand. It is, therefore, questionable if both groups had truly understood this mathematical idea when discussing it and were, in fact, associating it with linear or any other type of growth.

In line with the idea that the Great Acceleration and planetary boundary transgression are driven by an increase in the world's population, the majority of the students of both grades, also perceive the control of population growth as the best means of restricting human activity within planetary boundaries (student conception 5). The students reasoned that a lesser number of people would lead to lesser environmental degradation. While the senior secondary students argue more often that the increased consumption of natural resources and energy are leading to GEC, the junior secondary students claim that the destruction of ecosystems in general is the primary reason for GEC.

To control population growth, many of the junior secondary students and a few of the senior secondary students proposed a one-child policy, similar to that used in China (student conception 6). However, many of those students doubted if it would be globally feasible from a political perspective. In both groups, most of the students did not believe that we could exert any influence on population growth, arguing that only war and natural disasters could lead to the stagnation of the global population (student conception 7). However, they believed these effects would be short-lived, as the world's population would recover afterwards. More than one-third of the senior secondary students and fewer of the junior secondary students believed the development of new, sustainable technologies could be an additional means to stay within the planetary boundaries (student conception 8 ). They mostly referred to various examples of renewable energy usage, such as solar panels, hydropower, or wind power. Some of 
Table 2 Students' conceptions

\begin{tabular}{|c|c|c|c|}
\hline & Students` conceptions & Example statement & $\begin{array}{l}\text { Interviews } \\
\text { incidence }\end{array}$ \\
\hline 1 & $\begin{array}{l}\text { Population Growth Driving the } \\
\text { Great Acceleration }\end{array}$ & $\begin{array}{l}\text { "A larger population is multiplying faster, and human } \\
\text { beings are getting older and older, so the } \\
\text { acceleration of the graphs increases." (Urs) }\end{array}$ & $50 \%$ \\
\hline 2 & $\begin{array}{l}\text { Population Growth Leading to } \\
\text { More } \mathrm{CO}_{2} \text { Emissions }\end{array}$ & $\begin{array}{l}\text { "Large population growth is clearly connected to the } \\
\text { emission of } \mathrm{CO}_{2} \text {. And that's problematic because the } \\
\text { Earth is getting warmer and that could lead to big } \\
\text { problems in the future and make the Earth more and } \\
\text { more unstable." (Ivan) }\end{array}$ & $71 \%$ \\
\hline 3 & $\begin{array}{l}\text { Population Growth Driving } \\
\text { Biodiversity Loss and Climate } \\
\text { Change }\end{array}$ & $\begin{array}{l}\text { "Nature was fully dried up afterwards and nothing } \\
\text { could grow again, and no animals could survive. } \\
\text { What humans do, with a clear conscience, only for } \\
\text { business and money, makes you speechless." } \\
\text { (Hannah) } \\
\text { "Population growth has certainly pushed climate } \\
\text { change and species extinction boundaries. For } \\
\text { example, with the increase in population, people are } \\
\text { taking up more space and more cars are producing } \\
\text { more } \mathrm{CO}_{2}, \text { leading to species extinction and climate } \\
\text { change." (Ivan) }\end{array}$ & $93 \%$ \\
\hline 4 & $\begin{array}{l}\text { Continued Exponential Population } \\
\text { Growth }\end{array}$ & $\begin{array}{l}\text { "Population growth will continue to increase } \\
\text { exponentially." (Katrin) } \\
\text { "I expect [the population] to continue to increase } \\
\text { exponentially. It may perhaps stagnate for a while, } \\
\text { but the population will definitely increase } \\
\text { exponentially." (Hans) }\end{array}$ & $50 \%$ \\
\hline 5 & $\begin{array}{l}\text { Environmental Protection through } \\
\text { Population Control }\end{array}$ & $\begin{array}{l}\text { "Somehow we need to confront the problem of the } \\
\text { increasing and growing population. A decision must } \\
\text { be made to stop this population growth. China is an } \\
\text { example of this for us." (Urs) }\end{array}$ & $93 \%$ \\
\hline 6 & $\begin{array}{l}\text { Political Measures Stopping } \\
\text { Population Growth }\end{array}$ & $\begin{array}{l}\text { "Yes, well, I think we'll have a big environmental } \\
\text { problem if the population continues to increase. ... If } \\
\text { only we could stop it somehow? A one-child policy is } \\
\text { just utopic but, yes, it would be nice. Something has to } \\
\text { be done to ensure that the population doesn't get any } \\
\text { bigger." (Ute) }\end{array}$ & $57 \%$ \\
\hline 7 & $\begin{array}{l}\text { War and Catastrophes Stopping } \\
\text { Population Growth }\end{array}$ & $\begin{array}{l}\text { "We can't influence population growth. However, in a } \\
\text { world war, for example, more people would die than } \\
\text { normal. And, if a third world war were to happen } \\
\text { now, then the population figures would go down } \\
\text { again and then probably rise again. Or a } \\
\text { catastrophe, such as hurricanes, ... and simply } \\
\text { natural disasters that claim many lives." (Tina) }\end{array}$ & $57 \%$ \\
\hline 8 & $\begin{array}{l}\text { Technology Stopping Planetary } \\
\text { Boundary Transgression }\end{array}$ & $\begin{array}{l}\text { "I hope that in the future, we develop technologies that } \\
\text { allow us to drive back the red and yellow areas of the } \\
\text { planetary boundary framework." (Dieter) }\end{array}$ & $38 \%$ \\
\hline
\end{tabular}

the students also mentioned Tesla's Elon Musk and the company's electric cars as representative of innovative and sustainable technology, though their production is certainly not $\mathrm{CO}_{2}$ free. 


\section{Comparison of the scientists' and students' conceptions}

The conceptions of the junior and senior secondary school students were compared with the conceptions of the scientists to explore similarities and differences (RQ2). Table 3 summarizes the comparisons.

The comparison of the students' and the scientists' conceptions revealed one common idea: humanity is considered as a problem for the Earth. However, differences were also evident in their conceptions regarding population and economic growth (see Table 3). Students suggested that the growth of the world population was the main cause of the Great Acceleration (student conception 1), whereas the scientists explained that the Great Acceleration was caused by socioeconomic growth (scientist conception 1). Therefore, scientists took a stronger focus on economic growth as a cause also for an increase in $\mathrm{CO}_{2}$ emissions and generally GEC (scientists conceptions 2 and 3). Metaphorically, the economy is reified as an organism and resources as food for the economy (Wang et al., 2013). Students did not emphasize economic growth at all and reasoned that population growth was the cause for biodiversity loss, climate change, and GEC in general (student conception 3). They also believed that more people would lead to more $\mathrm{CO}_{2}$ emissions (student conception 2). However, scientists could show that economic activities mainly conducted by developed countries, such as foreign direct investment and fertilizer consumption, drove $\mathrm{CO}_{2}$ emissions, changes in the land system, and GEC in general. A person from a developed country-one with low population growth but a high GDP rate- emitted much more $\mathrm{CO}_{2}$ than a person from a developing country (Malm \& Hornborg, 2014; Steffen et al., 2015b). Furthermore, the impact of the increase in population on the Earth system was far less significant than that of continued economic growth.

While the students believed exponential population growth will continue in the future (student conception 4), scientists observed it will halt by the end of this century

Table 3 Comparison of the students' and scientists` conceptions

\begin{tabular}{|c|c|}
\hline Scientists conceptions & Student conceptions \\
\hline 1 Socioeconomic Growth Leading to the Great Acceleration & $\begin{array}{l}1 \text { Population Growth Driving the Great } \\
\text { Acceleration }\end{array}$ \\
\hline $\begin{array}{l}2 \text { Economic Growth Driving } \mathrm{CO}_{2} \text { Emissions } \\
3 \text { Economic Growth Leading to Global Environmental Change }\end{array}$ & $\begin{array}{l}2 \text { Population Growth Leading to More } \\
\mathrm{CO}_{2} \text { Emissions } \\
3 \text { Population Growth Driving Biodiversity } \\
\text { Loss and Climate Change }\end{array}$ \\
\hline 4 Decline in Exponential Population Growth & $\begin{array}{l}4 \text { Continued Exponential Population } \\
\text { Growth }\end{array}$ \\
\hline $\begin{array}{l}5 \text { Planetary Boundary Compliance through Green Economic } \\
\text { Growth } \\
6 \text { Planetary Boundary Compliance through Decoupling of } \\
\text { Economic Growth and Environmental Impact }\end{array}$ & $\begin{array}{l}5 \text { Environmental Protection through } \\
\text { Population Control } \\
6 \text { Political Measures Stopping Population } \\
\text { Growth } \\
7 \text { War and Catastrophes Stopping } \\
\text { Population Growth } \\
8 \text { Technology Stopping Planetary } \\
\text { Boundary Transgression }\end{array}$ \\
\hline
\end{tabular}

7 Economic Growth Is Still Coupled with Environmental Impact No students' conception 
(Steffen et al., 2015b, scientists conception 4). Scientists supported a green economic growth and a decoupling of economic growth from global environmental impacts (scientist conceptions 5 and 6) as a potential sustainable solution for planetary boundary compliance. However, students mentioned about political regulations aimed at controlling the world's population (student conceptions 5 and 6), war and catastrophes that could lead to a reduction in the world's population (student conception 7), and development of new sustainable technologies (student conception 8) as possible solutions. The scientists explained that decoupling of economic growth from environmental impact could result in continued economic growth within planetary boundaries theoretically, though no such permanent and global decoupling has taken place to date (scientist conception 7).

\section{Instructional guidelines derived from the comparison}

Students' conceptions provide a crucial basis for creating useful learning content. Based on students' conceptions, the teacher can create learning content that enhances students to reconstruct their pre-conceptions (Duit \& Treagust, 2003; Treagust \& Duit, 2008). Accordingly, we developed instructional guidelines (RQ3) based on a comparison of the students' and scientists' conceptions (RQ2) in order to enhance the reconstruction of students' conceptions into more scientific ones. The guidelines are based on observations that need to be considered in the planning of lessons on planetary boundaries and Great Acceleration graphs. These are formulated so that teachers may implement them according to the learning levels of their students.

Comparison of the students' and scientists' conceptions reveals the differences in their opinions. The students believe that the world population growth is the reason for the Great Acceleration of many Earth system changes and socioeconomic developments. However, the scientists show that it is the growth of the socioeconomic systems, especially of the developed OECD countries, who play the major role in the Great Acceleration of primary energy use, water use, paper production, transportation, tropical forest loss, nitrogen to coastal zone, stratospheric ozone, marine fish capture, and terrestrial biosphere degradation (Steffen et al., 2015b). Therefore, it is necessary that the students reflect upon their conception of "Population Growth Driving the Great Acceleration." They need to develop and reconstruct their conceptions to understand that they cannot find the cause in the number of people. The cause rather lies in the economic activities of the developed countries as per the following guideline:

1. The students should critically reflect on the growth of the world population resulting in the Great Acceleration and recognize the economic activities of the developed countries and economic growth as the main cause for the Great Acceleration and GEC.

To implement this guideline in the classroom, real societal challenges (Karpudewan \& Roth, 2018), including socio-scientific issue-based tasks are suitable. They have the advantage of multiple perspectives being included in the lesson: environment, society, economy, and technology. This, in turn, allows students to relate the content of the lessons to the world outside the classroom. With an implementation of socio-scientific 
activities in the curriculum, students can critically examine their conceptions and are encouraged to argue in a more evidence-based manner (Karpudewan \& Roth, 2018; Wang et al., 2017). Additionally, students see world population growth as the main driver of the global increase in $\mathrm{CO}_{2}$ emissions (student conception 2), whereas actual data demonstrates that the increase of GDP in dollars per capita leads to $\mathrm{CO}_{2}$ increase (scientist conception 2). To address this gap and also to help students to reconstruct their conception, the following guideline has been developed:

2. The students should critically reflect on the conception that population growth is the main driver for $\mathrm{CO}_{2}$ emissions and comprehend the connection between economic growth and $\mathrm{CO}_{2}$ emissions.

To put this guideline into practice in the classroom, problem-based and authentic learning situations on the topic of $\mathrm{CO}_{2}$ emissions polluters can be developed to engage students in solving authentic problems (Huang et al., 2019). For example, data on $\mathrm{CO}_{2}$ emissions from a populous country such as Ethiopia ( 0.1 metric tons $\mathrm{CO}_{2}$ per capita per year, 114.9 million people) can be compared with data on $\mathrm{CO}_{2}$ emissions from a low population but a developed country such as Finland (8.3 metric tons $\mathrm{CO}_{2}$ per capita per year, 5.5 million people; Worldometers.info, 2021; World Bank, 2021). As Malm and Hornborg illustrate, "a single average US citizen emitted as much as upwards of 500 citizens of Ethiopia, Chad, Afghanistan, Mali, Cambodia or Burundi” (2014, p. 64).

Furthermore, students believe in a constant exponential growth of the world population. However, the scientists show that the exponential growth will halt at the end of this century (Friedlingstein et al., 2014; Steffen et al., 2015b). The following guideline may help resolve this gap while aiding students to reconstruct their conception:

3. The students should critically reflect on the conception of the continuous exponential growth of the world population and understand that exponential population growth may stop at the end of this century.

In order to convey this guideline in class, it is suitable to discuss factors that lead to population growth and stagnation as well as to deal with the concept of exponential growth. One of the fundamental goals of mathematics education is to provide students with the ability to apply their mathematical knowledge to solve real-world problems (Loi \& Khanh, 2020). For example, tasks may include exploring the reason behind economically strong countries tending to have a low population growth rate, while economically weak countries tending to have a high growth rate (Loi \& Khanh, 2020).

Moreover, the students showed several different conceptions for planetary boundary compliance (see Table 2). The scientists explained that with a green growth and a decoupling of economic growth from environmental impact, it should be possible to stay within the boundaries. However, the data shows that no permanent and absolute decoupling from economic growth and environmental impacts has happened to date (Friedlingstein et al., 2014; Steffen et al., 2015b). Hence, this conception of the scientists requires critical reflection. Current economic growth is still based on a system that requires unlimited access to finite Earth system resources. The economy follows a linear "take-make-dispose" model: companies extract materials, apply energy and labor to manufacture a product, and sell the product to an end consumer, who then discards it 
once it no longer serves the user's purpose (MacArthur, 2013). This is supported by current resource prices: extracting new resources is cheaper than reusing alreadyextracted materials. Ludwig et al. (1993) explain that local politicians and parties often support such resource extraction because it promises rapid and high profits. Furthermore, the current system ensures that environmental damage is rendered positively in measurements of GDP: when the environment is degraded due to economic activity, its rehabilitation requires yet further economic activity. It is, therefore, clear that the existing economic system incentivizes further ecological damage. Accordingly, the following guideline has been developed, which will help students to further develop their conceptions to understand that the economic system must be fundamentally changed (O’Neill et al., 2018):

4. The students should critically reflect on world population control as a possibility for environmental protection and new technologies for planetary boundary compliance. They should be able to discuss the change of the current socioeconomic system as a sustainable solution for staying within planetary boundaries.

To implement this guideline in the classroom, teaching possibilities such as the creative problem solving (CPS) method may be appropriate. According to Huang et al. (2019), solutions of the complex real-world problem should not be developed from the problem, but the solution should be discussed backward from the ideal solution to the problem. In the classroom, this can be achieved by mobilizing students' imagination to virtually or physically construct an ideal socioeconomic system, which enables human development without adding burden to the environment. From this ideal system, they can think backwards to explore the socioeconomic and political measures that have to be taken to reach an ideal socioeconomic system, which will exist in symbiosis with the earth system (Huang et al., 2019). Lastly, it is important that the students understand that solutions to these dilemmas cannot be found in draconian controls of the world population; rather, the change must take place in the extant global economic systema system that, by its very nature, supports unsustainable economic activities.

\section{Discussion}

In our prior publications (2018, 2019), we had discussed the scientists' and students' conceptions about planetary boundary framework from different perspectives using methodological approach MER. In this article, in addition to planetary boundaries, we have focused on developing instructional guidelines for content related to global socioeconomic developments, including economic and population growth and their effects on GEC. Our results show that there are numerous differences in the understandings of the students and the scientists regarding planetary boundary transgression and Great Acceleration. The first three instructional guidelines were developed to address these gaps in students' understanding. They allowed students to reflect on the idea that population growth is causal for GEC. In this regard, the integration of socio-scientific issues-based tasks in the classroom is suitable, because it allows students to work in an interdisciplinary manner and stimulates critical thinking (Karpudewan \& Roth, 2018; Wan \& Bi, 2019; Wang et al., 2017). Such discussions about socio-scientific issues should include interrelations between politics, economics, 
and environment at different levels and be critical as well as complex in order to enhance the reconstruction of their conceptions (Bossér \& Lindahl, 2020; Chu \& Treagust, 2014; Sormunen, Juuti, \& Lavonen, 2019; Wan \& Bi, 2019; Wang et al., 2018).

In our study, we observed that students believed in controlling the world population to remain within the planetary boundaries. The scientists, on the other hand, advocated that growth within the planetary boundaries should be possible through Green Growth and decoupling of economic growth from environmental impact. However, they also mentioned that decoupling was yet to take place. Hence, it is questionable if such a global and absolute decoupling will ever take place. The last guideline addresses this gap and can be used to discuss solutions to GEC in the context of the current socioeconomic system. The creative problem solving (CPS) method (Huang et al., 2019) is suitable for this purpose as it develops solutions of the complex real-world problem not starting from the problem, but backwards from the ideal situation to the problem. Also, teaching approaches, which involve active student participation in topic-related problem-solving processes and give them the freedom to critically reflect on different perspectives, allow students to better understand complex environmental topics (Bossér \& Lindahl, 2020; Huang et al., 2019; Karpudewan \& Roth, 2018; Wang et al., 2018).

In conclusion, educational reconstructed guidelines provide an optimal basis for conveying knowledge about GEC both from scientific and political perspectives. These guidelines can be used to develop an overarching understanding that the stability of the Earth system can only be maintained with international cooperation and implementation of planetary boundaries. As Rockström and Klum (2015) point out, "How a worker commutes in Stockholm affects the farmer in Ecuador." (p. 17). The guidelines enable to communicate key concepts, including interconnectedness, the urgency of environmental problems, and a general mind-shift to reconnect humanity with the earth. Neither a society nor an economy can function without a stable nature. Ultimately, education aims to impart values and attitudes to understand how political decisions and socioeconomic systems have a significant impact on the quest for planetary boundary compliance (Davies \& Lundholm, 2012).

\section{Funding Open Access funding provided by Universität Zürich.}

Open Access This article is licensed under a Creative Commons Attribution 4.0 International License, which permits use, sharing, adaptation, distribution and reproduction in any medium or format, as long as you give appropriate credit to the original author(s) and the source, provide a link to the Creative Commons licence, and indicate if changes were made. The images or other third party material in this article are included in the article's Creative Commons licence, unless indicated otherwise in a credit line to the material. If material is not included in the article's Creative Commons licence and your intended use is not permitted by statutory regulation or exceeds the permitted use, you will need to obtain permission directly from the copyright holder. To view a copy of this licence, visit http://creativecommons.org/licenses/by/4.0/.

\section{References}

Baur, N., \& Blasius, J. (2019). Handbuch Methoden der empirischen Sozialforschung [Manual of empirical social research]. Springer Publisher's.

Bass, S. (2009). Planetary boundaries: keep off the grass. Nature Climate Change, 1(1), 113-114.

Bossér, U., \& Lindahl, M. (2020). Teachers' coordination of dialogic and authoritative discourses promoting specific goals in socio scientific issue-based teaching. International Journal of Science and Mathematics Education, 19(3), 461-482. 
Brennan, R. L., \& Prediger, D. J. (1981). Coefficient kappa: some uses, misuses, and alternatives. Educational and Psychological Measurement, 41(3), 687-699.

Chhokar, K., Dua, S., Taylor, N., Boyes, E., \& Stanisstreet, M. (2011). Indian secondary students' views about global warming: beliefs about the usefulness of actions and willingness to act. International Journal of Science and Mathematics Education, 9(5), 1167-1188.

Chu, H. E., \& Treagust, D. F. (2014). Secondary students' stable and unstable optics conceptions using contextualized questions. Journal of Science Education and Technology, 23(2), 238-251.

Dao, Q., Peduzzi, P., Chatenoux, B., De Bono, A., Schwarzer, S., \& Friot, D. (2015). Environmental limits and swiss footprints based on planetary boundaries. In Geneva: Swiss Federal Office for the Environment (FOEN). Retrieved from https://archive-ouverte.unige.ch/unige:74873

Davies, P., \& Lundholm, C. (2012). Students' understanding of socio-economic phenomena: conceptions about the free provision of goods and services. Journal of Economic Psychology, 33(1), 79-89.

Dresing, T., Pehl, T., \& Schmieder, Ch. (2015). Manual (on) Transcription. Transcription Conventions, Software Guides and Practical Hints for Qualitative Researchers. $3^{\text {rd }}$ English Edition. Retrieved from https://www.audiotranskription.de/wpcontent/uploads/2020/11/manual-on-transcription.pdf

Duit, R., \& Treagust, D. (2003). Conceptual change - a powerful framework for improving science teaching and learning. International Journal of Science Education, 25(1), 671-688.

Duit, R., Gropengiesser, H., Kattmann, U., Parchmann, I., \& Komorek, M. (2012). The model of educational reconstruction - a framework for improving teaching and learning science. In D. Jorde \& J. Dillon (Eds.), Science Education Research and Practice in Europe (pp. 13-38). Sense Publishers.

Federal Statistical Office (2009). Demographic portrait of Switzerland. Retrieved May 01, 2020, from https:// www.bfs.admin.ch/bfs/en/home/statistics/population/population-projections.assetdetail.346792.html

Felzmann, D. (2017). Students' conceptions of glaciers and ice ages: applying the model of educational reconstruction to improve learning. Geoscience Education, 65(3), 322-335.

Flick, U. (2015). Introducing research methodology: A beginner's guide to doing a research project. SAGE Publishers.

Forbes, C., Vo, T., Zangori, L., \& Schwarz, C. (2015). Scientific models help students understand the water cycle. Science and Children, 53(2), 42-49.

Friedlingstein, P., Andrew, R. M., Rogelj, J., Peters, G. P., Canadell, J. G., Knutti, R., Luderer, G., Raupach, M. R., Schaeffer, M., van Vuuren, D. P. \& Le Quéré, C. (2014). Persistent growth of $\mathrm{CO}_{2}$ emissions and implications for reaching climate targets. Nature Geoscience, 7(1), 709-715.

Frischknecht, R., Stolz, P., \& Tschümperlin, L. (2016). National environmental footprints and planetary boundaries: from methodology to policy implementation. The International Journal of Life Cycle Assessment, 21(4), 601-605.

Glaser-Zikuda, M., Hagenauer, G., \& Stephan, M. (2020). The potential of qualitative content analysis for empirical educational research. Forum: Qualitative Social Research, 21(1), 1-20.

Gropengiesser, H. (2007). Theorie des erfahrungsbasierten Verstehens [The theory of embodied cognition]. In D. Krüger \& E. Vogt (Eds.), Theorien in der biologiedidaktischen Forschung: Ein Handbuch für Lehramtsstudenten und Doktoranden [Theories of educational research in biology: A handbook for teachers and $\mathrm{PhD}$ students] (pp. 105-112). Springer.

Gropengiesser, H. (2008). Qualitative Inhaltsanalyse in der fachdidaktischen Lehr- Lernforschung [Qualitative content analysis in teaching and learning research]. In P. Mayring \& M. Glaeser-Zikuda (Eds.), Die Praxis der Qualitativen Inhaltsanalyse [The practise of qualitative content analysis] (pp. 172-189). Beltz Publishers.

Helfferich, C. (2011). Die Qualität qualitativer Daten [The quality of qualitative data]. Publisher`s for Social Science.

Huang, T. C., Lin, W., \& Yueh, H. P. (2019). How to cultivate an environmentally responsible maker? A CPS approach to a comprehensive maker education model. International Journal of Science and Mathematics Education, 17(1), 49-64.

Ignell, C., Davies, P., \& Lundholm, C. (2017). Understanding "price" and the environment: exploring upper secondary students' conceptual development. Journal of Social Science Education, 16(1), 68-80.

Johnson, M. (1987). The body in the mind: In The bodily basis of meaning, imagination, and reason. University of Chicago Press.

Karpudewan, M., \& Roth, W. M. (2018). Changes in primary students' informal reasoning during an environment-related curriculum on socio-scientific issues. International Journal of Science and Mathematics Education, 16(3), 401-419.

Kattmann, U., Duit, R., Gropengiesser, H., \& Komorek, M. (1997). Das Modell der didaktischen Rekonstruktion - Ein Rahmen für naturwissenschaftsdidaktische Forschung und Entwicklung [The model of educational reconstruction - a framework for science education research and development]. Zeitschrift für Didaktik der Naturwissenschaften, 3(3), 3-18. 
Kersting, M., Henriksen, E. K., Bøe, M. V., \& Angell, C. (2018). General relativity in upper secondary school: design and evaluation of an online learning environment using the model of educational reconstruction. Physical Review Physics Education Research, 14(1), 1-18.

Komorek, M., \& Kattmann, U. (2008). The model of educational reconstruction. In S. Mikelskis-Seifert, U. Ringelband \& M. Brückmann (Eds.), Four decades of research in science education-from curriculum development to quality improvement (pp. 171-188). Waxmann Publishers.

Komendantova, N., \& Neumueller, S. (2020). Discourses about energy transition in Austrian climate and energy model regions: turning awareness into action. Energy \& Environment, 31(8), 1-20.

Lakoff, G., \& Johnson, M. (2008). Metaphors we live by. University of Chicago Press.

Lampert, I. \& Niebert, K. (2018). Alltagsvorstellungen zu den planetaren Belastungsgrenzen [Everyday conceptions about the planetary boundaries]. In M. Hammann \& M. Lindner (Eds.), Lehr- und Lernforschung in der Biologiedidaktik (Bd. 8, S. pp. 15-30). Studienverlag.

Lampert, I., \& Niebert, K. (2019). Den globalen Wandel verstehen: Vorstellungen zur Stabilität und Instabilität der Erdsysteme [Understanding global environmental change. Conceptions about the stability and instability of the Earth system]. Zeitschrift für Didaktik Der Biologie (ZDB)-Biologie Lehren Und Lernen, 23(1), 39-58. https://doi.org/10.4119/zdb-1739.

Lavallée, M., Robillard, P. N., \& Mirsalari, R. (2014). Performing systematic literature reviews with novices: an iterative approach. IEEE Transactions on Education, 57(3), 175-181.

Liu, S. C., \& Lin, H. S. (2014). Undergraduate students' science-related ideas as embedded in their environmental worldviews. International Journal of Science and Mathematics Education, 12(5), 1001-1021.

Loi, N. H., \& Khanh, T. L. C. (2020). Connecting mathematics and practice: a case study of teaching exponential functions. European Journal of Education Studies, 7(12), 612-623.

Ludwig, D., Hilborn, R., \& Walters, C. (1993). Uncertainty, resource exploitation, and conservation: lessons from history. Science, 260(5104), 17-36.

MacArthur, E. (2013). Towards the circular economy. Journal of Industrial Ecology, 2(1), 23-44.

Mahler, R. L. (2020). University student views of local versus global environmental issues. Natural Sciences Education, 49(e20016), 1-14.

Malm, A., \& Hornborg, A. (2014). The geology of mankind? A critique of the Anthropocene narrative. The Anthropocene Review, 1(1), 62-69.

Mayring, Ph. (2000). Qualitative Inhaltsanalyse [Qualitative content analysis]. Forum: Qualitative Social Research, 1(2), Art. 20.

Mayring, Ph. (2015). Qualitative content analysis: theoretical background and procedures. In A. BiknerAhsbahs, C. Knipping \& N. Presmeg (Eds.), Approaches to qualitative research in mathematics education. Advances in mathematics education (pp. 365-380). Springer.

Nash, K. L., Cvitanovic, C., Fulton, E. A., Halpern, B. S., Milner-Gulland, E. J., Watson, R. A., \& Blanchard, J. L. (2017). Planetary boundaries for a blue planet. Nature Ecology \& Evolution, 1(11), 1625-1634.

Nuraeni, H., Rustaman, N. Y., \& Hidayat, T. (2017). Teachers' understanding of biodiversity, conservation, and hotspots biodiversity concepts. Advances in Social Science, Education and Humanities Research (ASSEHR), 57(1), 252-256.

O’Neill, D. W., Fanning, A. L., Lamb, W. F., \& Steinberger, J. K. (2018). A good life for all within planetary boundaries. Nature Sustainability, 1(2), 88-95.

Reinfried, S., Aeschbacher, U., Kienzler, P. M., \& Tempelmann, S. (2015). The model of educational reconstruction - a powerful strategy to teach for conceptual development in physical geography: the case of water springs. International Research in Geographical and Environmental Education, 24(3), 237-257.

Rockström, J., Steffen, W., Noone, K., Persson, Å., Chapin, F. S., Lambin III, E., Lenton, T. M., Scheffer, M., Folke, C., Schellnhuber, H., Nykvist, B., De Wit, C. A., Hughes, T., van der Leeuw, S., Rodhe, H., Sörlin, S., Snyder, P. K., Costanza, R., Svedin, U., . . . Foley, J. (2009). Planetary boundaries: exploring the safe operating space for humanity. Ecology and Society, 14(2), 32 [online]. http://www.ecologyandsociety. org/vol14/iss2/art32/.

Rockström, J., \& Klum, M. (2015). Big world, small planet: abundance within planetary boundaries. Yale University Press.

Schmitt, R. (2005). Systematic metaphor analysis as a method of qualitative research. The Qualitative Report, $10(2), 358-394$.

Schlesinger, W. (2009). Planetary boundaries: thresholds risk prolonged degradation. Nature Climate Change, $1(1), 112-113$.

Schneider, M., Vamvakoussi, X. \& Van Dooren, W. (2012). Conceptual change. In N.M. Seel (Eds.), Encyclopedia of the Sciences of Learning (pp. 735-738). Springer.

Shepardson, D. P., Niyogi, D., Choi, S., \& Charusombat, U. (2009). Seventh grade students' conceptions of global warming and climate change. Environmental Education Research, 15(5), 549-570. 
Steffen, W., Sanderson, R. A., Tyson, P. D., Jäger, J., Matson, P. A., Moore III, B., Oldfield, F., Richardson, K., Schellnhuber, H. J., Turner II, B. L. \& Wasson, R. J. (2004). Global change and the earth system: a planet under pressure. Springer.

Steffen, W., Richardson, K., Rockström, J., Cornell, S. E., Fetzer, I., Bennett, E. M., Biggs, R., Carpenter, S. R., de Vries, W., de Wit, C. A., Folke, C., Gerten, D., Heinke, J., Mace, G. M., Persson, L. M., Ramanathan, V., Reyers, B. \& Sörlin, S. (2015a). Planetary boundaries: guiding human development on a changing planet. Science, 347(6223), 736-746.

Steffen, W., Broadgate, W., Deutsch, L., Gaffney, O., \& Ludwig, C. (2015b). The trajectory of the Anthropocene: the great acceleration. The Anthropocene Review, 2(1), 81-98.

Sternäng, L., \& Lundholm, C. (2012). Climate change and costs: investigating students' reasoning on nature and economic development. Environmental Education Research, 18(3), 417-436.

Sormunen, K., Juuti, K., \& Lavonen, J. (2019). Maker-centered project-based learning in inclusive classes: supporting students' active participation with teacher-directed reflective discussions. International Journal of Science and Mathematics Education, 18(4), 691-712.

Thackeray, S. J., Robinson, S. A., Smith, P., Bruno, R., Kirschbaum, M. U. F., Bernacchi, C., Byrne, M., Cheung, W., Cotrufo, M. F., Gienapp, P., Hartley, S., Janssens, I., Hefin Jones, T., Kobayashi, K., Luo, Y., Penuelas, J., Sage, R., Suggett, D. J., Way, D., \& Long, S. (2020). Civil disobedience movements such as school strike for the climate are raising public awareness of the climate change emergency. Global Change Biology, 26(3), 1042-1044.

Treagust, D. F., \& Duit, R. (2008). Conceptual change: a discussion of theoretical, methodological and practical challenges for science education. Cultural Studies of Science Education, 3(2), 297-328.

Uman, L. S. (2011). Systematic reviews and meta-analyses. Journal of the Canadian Academy of Child and Adolescent Psychiatry, 20(1), 57-64.

Wan, Y., \& Bi, H. (2019). What major "socio-scientific topics" should the science curriculum focused on? A Delphi study of the expert community in China. International Journal of Science and Mathematics Education, 18(1), 61-77.

Wang, H., Runtsova, T., \& Chen, H. (2013). Economy is an organism-a comparative study of metaphor in English and Russian economic discourse. Text \& talk, 33(2), 259-288.

Wang, H. H., Hong, Z. R., Liu, S. C., \& Lin, H. S. (2018). The impact of socio-scientific issue discussions on student environmentalism. EURASIA Journal of Mathematics, Science and Technology Education, 14(12), 1-15.

Wang, H. H., Chen, H. T., Lin, H. S., Huang, Y. N., \& Hong, Z. R. (2017). Longitudinal study of a cooperation-driven, socio-scientific issue intervention on promoting students' critical thinking and selfregulation in learning science. International Journal of Science Education, 39(15), 2002-2026.

World Bank. World Development Indicators. Retrieved February 5, 2021, from https://databank.worldbank. org/reports.aspx?source=2\&series=EN.ATM.CO2E.PC\&country=

World Health Organization. Global environmental change. Retrieved July 29, 2020, from https://www.who. int/globalchange/climate/en/

Worldometers.info. Countries in the world by population 2021. Retrieved February 5, 2021, from https:// www.worldometers.info/world-population/population-by-country

\title{
Affiliations
}

\section{Irene Lampert ${ }^{1} \cdot$ Kai Niebert ${ }^{1} \cdot$ Markus Wilhelm $^{2}$}

\author{
Kai Niebert \\ kai.niebert@uzh.ch \\ Markus Wilhelm \\ markus.wilhelm@phz.ch
}

1 Chair of Science and Sustainability Education, University of Zurich, Kantonsschulstrasse 3, CH8001 Zürich, Switzerland

2 Chair of the Institute for Science Education and Social Studies, University of Lucerne, Sentimatt 1, CH6003 Luzern, Switzerland 